\title{
ANALISIS ALOKASI DANA DESA DI KEBUPATEN LEBONG TAHUN 2016
}

\section{ANALYSIS OF VILLAGE FUND INSTRUMENTS (DD) IN LEBONG DISTRICT IN 2016}

\author{
Nosy Mayasari $\left.{ }^{1}\right)$, Abdullah $^{2}$ ) \\ Universitas Bengkulu, Jl. WR. Supratman,Kandang Limun, Muara Bangkahulu, \\ Bengkulunossymys@gmail,com ${ }^{1}$ ),Abdullah@unib.ac.id ${ }^{2}$ )
}

\begin{abstract}
This study aims to analyze whether the procedure of allocation of Village Funds in Lebong Regency has been in accordance or not in accordance with Regulation of the Minister of Finance RI No.49 of 2016 on Procedure of Allocation of Village Funds. This research uses descriptive research approach. The data used in this study is secondary data, in the form of Lebong Village Fund (DD) data issued by Minister of Finance Regulation No. 49 of 2016, population, area, poverty rate, and geographical difficulties index. The object of research in this study as many as 12 District in Lebong District. The results of the research analysis indicate that the procedures for allocating village funds have followed the guidelines of the applicable rules, but the data used in the calculation of Village Fund Allocation are not all sourced from the Central Bureau of Statistics of Lebong Regency while in the Minister of Finance Regulation No.49 of 2016 Data must be sourced from the statistics field.
\end{abstract}

Key words: Village Fund Allocation

\section{ABSTRAK}

Penelitian ini bertujuan untuk menganalisis apakah tata carapengalokasian Dana Desa pada Kabupaten Lebong telah sesuai atau belum sesuai denganPeraturan Menteri Keuangan RI No.49 tahun 2016 tentang Tata Cara Pengalokasian Dana Desa. Penelitian ini menggunakan penelitian pendekatan deskriptif. Data yang digunakan pada penelitian ini adalah data sekunder, berupa data Pagu Dana Desa (DD) Kabupaten Lebong yang dikeluarkan oleh Peraturan Menteri Keuangan No 49 Tahun 2016,jumlah penduduk, luas wilayah, angka kemiskinan, dan indeks kesulitan geografis.Objek penelitian dalam penelitian ini sebanyak 12 Kecamatan di Kabupaten Lebong. Hasil analisis penelitian menunjukkan bahwa tata cara pengalokasian dana desa sudah mengikuti petunjuk dari aturan yang berlaku, tetapi data-data yang digunakan dalam perhitungan Pengalokasian Dana Desa tidak semua bersumber dari Badan Pusat Statistik Kabupaten Lebong sedangkan di dalam Peraturan Menteri Keuangan No.49 tahun 2016 sumber data harus bersumber dari bidang statistik.

Kata kunci :Pengalokasian Dana Desa

\section{PENDAHULUAN}

Sesuai dengan UU. No 23 tahun 2014 tentang Pemerintahan Daerah bahwa penyelenggaraan Pemerintahan Daerah, diarahkan untuk mempercepat terwujudnya kesejahteraan masyarakat melalui peningkatan pelayanan, pemberdayaan, peran serta masyarakat dan peningkatan daya saing daerah dengan memperhatikan prinsip demokrasi, pemerataan, keadilan dan kekhasan suatu daerah dalam Sistem Negara Kesatuan Republik Indonesia. Oleh karena itu, Pemerintah Daerah berhak untuk mengatur dan mengurus sendiri urusan Pemerintahan menurut asas otonom. Pelaksanaan Otonomi Daerah merupakan sarana Pemerintah untuk melaksanakan reformasi administrasi ditubuh Pemerintah dan bertujuan untuk memperbaiki praktek penyelenggaraan Pemerintahan di Indonesia. Hal ini 
didukung dengan diberlakukannya Undang-Undang No. 23 Tahun 2014 tentang Pemerintahan Daerah.

Pelaksanaan Otonomi Daerah yang baik harus didukung oleh semua pihak yang terkait, baik dari segi sumber dana (anggaran) serta sumber daya alam. Akan tetapi sumber daya tersebut tidak boleh dibiarkan saja namun harus dikelola secara maksimal agar menghasilkan sumber dana untuk daerah. Efisiensi dan efektivitas penyelenggaraan Pemerintahan Daerah perlu ditingkatkan dengan lebih memperhatikan aspek-aspek hubungan antara Pemerintah Pusat dengan daerah dan antar daerah. Pada UU No. 23 tahun 2014 menjelaskan tentang daerah yang bersifat otonom dalam pelaksanaan kegiatan Pemerintahan menerapkan asas desentralisasi. Desentralisasi keuangan dan otonomi daerah adalah wujud dari reformasi yang mengharapkan tata kelola Pemerintah yang baik, pelaksanaan dari Pemerintahan yang baik dapat dilihat dengan adanya transparansi dan akuntabilitasi. Dimana setiap informasi yang bersifat umum dapat diakses dengan mudah bagi pihak yang membutuhkan. Tujuan umum kebijakan otonomi daerah/desentralisasi adalah memberi peluang dan kesempatan bagi terwujudnya Pemerintah yang baik terkait, baik dari segi sumber dana (anggaran) serta sumber daya alam. Akan tetapi sumber daya tersebut tidak boleh dibiarkan saja namun harus dikelola secara maksimal agar menghasilkan sumber dana untuk daerah. Efisiensi dan efektivitas penyelenggaraan Pemerintahan Daerah perlu ditingkatkan dengan lebih memperhatikan aspek-aspek hubungan antara Pemerintah Pusat dengan daerah dan antar daerah. Pada UU No. 23 tahun 2014 menjelaskan tentang daerah yang bersifat otonom dalam pelaksanaan kegiatan Pemerintahan menerapkan asas desentralisasi. Desentralisasi keuangan dan otonomi daerah adalah wujud dari reformasi yang mengharapkan tata kelola Pemerintah yang baik, pelaksanaan dari Pemerintahan yang baik dapat dilihat dengan adanya transparansi dan akuntabilitasi. Dimana setiap informasi yang bersifat umum dapat diakses dengan mudah bagi pihak yang membutuhkan. Tujuan umum kebijakan otonomi daerah/desentralisasi adalah memberi peluang dan kesempatan bagi terwujudnya Pemerintah yang baik dan bersih di daerah, dimana pelaksanaan tugas Pemerintah Daerah harus didasarkan atas prinsip efektif, efisien, terbuka, dan akuntabel.

Terdapat tiga misi utama pelaksanaan otonomi daerah dan desentralisasi fiskal, yaitu meningkatkan kualitas dan kuantitas pelayanan publik serta kesejahteraan masyarakat, menciptakan efisiensi dan efektifitas pengelolaan sumber daya daerah, dan memberdayakan dan menciptakan ruang bagi masyarakat (publik) untuk berpartisipasi dalam proses pembangunan. Penyelenggaraan Pemerintahan Desa tidak terpisahkan daripenyelenggaraan otonomi daerah, dimana penyelenggaraan Pemerintahan Desa merupakan unit terdepan (ujung tombak) dalam pelayanan kepada masyarakat serta menjadi tonggak strategis untuk keberhasilan semua program yang dijalankan Pemerintah. Oleh sebab itu upaya untuk memperkuat desa (Pemerintahan Desa dan Lembaga Kemasyarakatan Desa) merupakan tahap awal untuk mempercepat terwujudnya kesejahteraan masyarakat sebagai hakikat dari otonomi daerah.

Berdasarkan Peraturan Pemerintah Nomor8Tahun2016 tentang Dana Desa (DD) yang bersumber dari APBN,bahwaDana Desa (DD) adalah dana yang bersumber dari Anggaran Pendapatan dan Belanja Negara yang diperuntukkan bagi Desa yang ditransfer melalui Anggaran Pendapatan danBelanjaDaerahkabupaten/kota. Dana desa dialokasikan oleh Pemerintah untuk Desa. Dengan bergulirnya dana-dana perimbangan tersebut melalui Dana Desa dapat menjadikan desa benar-benar sejahtera. Dana Desa dengan asas adil dan merata, tidak diskriminatif, transparan, mendorong kemajuan bagi desa penerima. Pedoman daerah untuk menghitung besarnya Dana Desa setiap desa berdasarkan Peraturan Menteri Keuangan Republik Indonesia Nomor: 49/PMK.07/2016 tentang tata cara pengalokasian, penyaluran, penggunaan, pemantauan dan evaluasi dana desa yang dijabarkan di dalam Peraturan Bupati. 
Pada tahun 2016 sumber dana di Kabupaten Lebong bersumber dari Anggaran Pendapatan dan Belanja Negara (APBN). Pemberian Dana Desa di Kabupaten Lebong, Pemerintah Kabupaten telah mengeluarkan Petunjuk Teknis melalui Peraturan Bupati Lebong No. 17 tahun 2016 tentang tata cara pembagian dan penetapan besaran dana desa setiap desa dalam kabupaten lebong tahun anggaran 2016. Dana Desa merupakan bantuan langsung yang dialokasikan kepada Pemerintah Desa, digunakan untuk meningkatkan sarana pelayanan masyarakat, kelembagaan dan prasarana desa. Dimana pemanfaatan dan administrasi pengelolaan dilakukan dan dipertanggung jawabkan oleh Kepala Desa.

Penelitian ini mengambil topik utama mengenai Dana Desa dengan tujuan untuk dapat melihat apakah dengan diberlakukannya kebijakan melalui Peraturan Bupati Lebong No. 17 tahun 2016 dalam pengalokasian Dana Desa telah sesuai aturan yang berlaku dengan menggunakan formula dan data-data yang bersumber dari lembaga/instansi yang berwenang berdasarkan asas adil dan merata. Asas adil untuk setiap Desa berdasarkan nilai bobot Desa yang dihitung berdasarkan empat variabel yaitu jumlah penduduk, jumlah penduduk miskin, luas wilayah dan indeks kesulitan geografis. Sedangkan asas merata adalah besarnya bagian Dana Desa yang sama untuk setiap Desa. Untuk itu diharapkan Dana Desa digunakan secara efektif dan efisien untuk meningkatkan pelayanan masyarakat yang merupakan tujuan dari desentralisasi yaitu mempercepat pembangunan dan pemerataan hasil pembangunan, serta memaksimalkan potensi daerah untuk membiayai kebutuhan daerah.

\section{KERANGKA TEORITIS DAN HIPOTESIS}

Daerah sebagai satu kesatuan masyarakat hukum yang mempunyai otonomi, berwenang mengatur dan mengurus daerahnya sesuai aspirasi dan kepentingan masyarakat sepanjang tidak bertentangan dengan tatanan hukum nasional dan kepentingan umum. Dalam rangka memberikan ruang yang lebih luas kepada daerah untuk mengatur dan mengurus kehidupan warga maka Pemerintah Pusat dalam membuat kebijakan harus memperhatikan kearifan lokal dan sebaliknya daerah ketika membentuk Kebijakan baik dalam bentuk Peraturan Daerah maupun kebijakanlainnya juga memperhatikanKepentingan Nasional.Dengan demikian akan tercipta keseimbangan antara kepentingan nasional yang sinergis dengan tetap memperhatikan kondisi, kekhasan, dan kearifan lokal dalam penyelenggaraan Pemerintahan secara keseluruhan.

Menurut Azam awang (2010) menyatakan bahwa "otonomi mengandung arti kemandirian untuk mengatur dan mengurus urusan (rumah tangganya) sendiri." Menurut Murtir Jeddawi (2006), Otonomi Daerah diartikan sebagai, "Otonomi Daerah adalah wewenang daerah untuk mengatur dan mengurus kepentingan masyarakat setempat sesuai prakarsa sendiri berdasarkan aspirasi masyarakat dan batas wewenang yang diberikan pemerintah sesuai peraturan perundang-undangan yang berlaku." Sedangkan dalam pasal 1 angka (6) Undangundang Nomor 23 tahun 20104 tentang Pemerintahan Daerah, menyebutkan bahwa

"Otonomi Daerah adalah hak, wewenang dan kewajiban daerah otonom untuk mengatur dan mengurus sendiri urusan pemerintahan dan kepentingan masyarakat setempat dalam Sistem Negara Kesatuan Republik Indonesia."

Menurut UU No.23 tahun 2014 pemberian otonomi yang seluas - luasnya kepada daerah diarahkan untuk mempercepat terwujudnya kesejahteraan masyarakat melalui peningkatan pelayanan, pemberdayaan, dan peran serta masyarakat. Melalui otonomi daerah diharapkan mampu meningkatkan daya saing dengan memperhatikan prinsip demokrasi, pemerataan, keadilan, keistimewaan dan kekhususan serta potensi dan keanekaragaman daerah dalam Sistem Negara Kesatuan Republik Indonesia.

Dalam Pasal 1 angka 2 Undang- Undang No. 23 tahun 2014 tentang Pemerintah Daerah disebutkan bahwa "Pemerintahan Daerah adalah penyelenggara urusan Pemerintah 
oleh Pemerintah Daerah dan Dewan Perwakilan Rakyat Daerah menurut asas otonomi dan tugas pembantuan dengan prinsip otonomi seluas- luasnya dalam Sistem dan Prinsip Negara Kesatuan Republik Indonesia sebagaimana dimaksud dalam Undang-Undang Dasar Negara Republik Indonesia tahun 1945. Sedangkan pada pasal 1 angka 3 Pemerintah Daerah adalah Kepala Daerah sebagai unsur penyelenggara Pemerintahan Daerah yang memimpin pelaksanaan urusan Pemerintahan yang menjadi kewenangan daerah otonomi. Pemerintah Daerah meliputi Gubernur, Bupati atau Walikota dan Perangkat Daerah sebagai unsur penyelenggara Pemerintahan Daerah. Berkaitan dengan hal itu peran Pemerintah Daerah adalah segala sesuatu yang dilakukan dalam bentuk cara tindakan, baik dalam rangka melaksanakan otonomi daerah sebagai suatu hak, wewenang dan kewajiban Pemerintah Daerah untuk mengatur dan mengurus sendiri urusan Pemerintahan dan kepentingan masyarakat setempat sesuai dengan Peraturan Perundang- Undangan.

Peraturan Daerah merupakan kebijakan umum pada tingkat daerah yang dihasilkan oleh lembaga eksekutif dan lembaga legislatif sebagai pelaksana asas desentralisasi dalam rangka mengatur dan mengurus rumah tangga daerah. Peraturan Daerah adalah salah satu produk Peraturan Perundang- Undangan tingkat daerah yang dibentuk oleh Kepala Daerah, baik Daerah Propinsi maupun Daerah Kabupaten/Kota dengan Dewan Perwakilan Rakyat Daerah Provinsi maupun Kabupaten Kota. Kewenangan daerah dalam membentuk Peraturan Daerah secara legalitas ditegaskan dalam Undang- Undang Nomor 23 Tahun 2014 tentang Pemerintahan Daerah pasal 1 angka 25 Peraturan Daerah yang selanjutnya disebut Perda atau yang disebut dengan nama lain adalah Perda Provinsi dan Perda Kabupaten/Kota dan secara teknis diatur lebih lanjut dalam Peraturan Perundang - Undangan lainnya. Dalam pembentukan peraturan daerah tidaklah mudah karena memerlukan pengetahuan dan pemahaman yang cukup terutama tentang teknik pembentukannya, sehingga peraturan daerah yang dibentuk tidak bertentangan dengan Peraturan Perundang-Undangan dan kepentingan umum.

Keuangan Daerah merupakan bagian integral dari Keuangan Negara dalam pengalokasian sumber-sumber ekonomi, pemerataan hasil-hasil pembangunan dan menciptakan stabilitas ekonomi guna stabilitas sosial politik. Peranan Keuangan Daerah menjadi semakin penting karena adanya keterbatasan dana yang dapat dialihkan ke daerah berupa subsidi dan bantuan. Peranan Keuangan Daerah akan dapat meningkatkan kesiapan daerah untuk mendorong terwujudnya otonomi daerah yang lebih nyata dan bertanggung jawab.

Penyerahan sumber Keuangan Daerah baik berupa pajak daerah dan retribusi daerah maupun berupa dana perimbangan merupakan konsekuensi adanya penyerahanurusan Pemerintahan kepada daerah yang diselenggarakan berdasarkanasas otonomi. Untuk menjalankan urusan Pemerintahan, daerah harus mempunyai sumber keuangan agar mampu memberikan pelayanan dan kesejahteraan kepada masyarakat di daerah. Pemberian sumber keuangan kepada daerah harus seimbang dengan beban atau urusan pemerintahan yang diserahkan kepada daerah. Keseimbangan sumber keuangan ini merupakan jaminan terselenggaranya urusan pemerintahan daerah.

Konsep otonomi desa sebenarnya adalah sebuah konsep yang dimaknai sebagai adanya kemampuan serta prakarsa masyarakat desa untuk dapat mengatur dan melaksanakan dinamika kehidupannya dengan didasarkan pada kemampuannya sendiri. Hal ini berarti bahwa intervensi dari luar desa sendiri sedapat mungkin untuk dihilangkan atau paling tidak dikurangi. Keberadaan otonomi desa merupakan sesuatu yang memang telah ada sejak desa itu mulai ada, dan bukan merupakan sebuah limpahan wewenang dari Negara. Hal tersebut berarti tidak semua wewenang yang dimiliki oleh daerah otonom dalam pelaksanaan kebijakan otonomi daerah juga sama dengan yang diterima oleh desa. Artinya otonomi desa lebih dimaknai sebagai adanya kemampuan serta prakarsa masyarakat desa untuk dapat mengatur dan melaksanakan dinamika kehidupannya dengan sedapat mungkin didasarkan pada kemampuannya sendiri dengan mengurangi intervensi pihak luar, berdasarkan wewenang 
yang dimilikinya dengan bersandar pada peraturan yang berlaku. Pemberlakuan kebijakan otonomi desa juga mengundang berbagai tanggapan serta pandangan, baik itu dari pemerintah maupun masyarakat.

Demi terlaksananya program- program pembangunan pedesaan perlu adanya desa-desa yang otonom dibentuk sebagai satu kesatuan masyarakat yang utuh. Setiap masyarakat perlu di beritanggung jawab dan peranan tertentu secara langsung dalam soal- soal pembangunan dan pemerintahan desa, sehingga masyarakat tidak hanya sebagai objek pembangunan akan tetapi juga sebagaisubjekdaripembangunanitu sendiri.

Menurut Undang-Undang No 6 Tahun 2014 tentang Desa pasal 1 angka 7 Peraturan Desa adalah peraturan perundang-undangan yang ditetapkan oleh Kepala Desa setelah dibahas dan disepakati bersama Badan Permusyawaratan Desa. Peraturan ini berlaku di wilayah desa tertentu. Peraturan Desa merupakan penjabaran lebih lanjut dari peraturan perundang-undangan yang lebih tinggi dengan memperhatikan kondisi sosial budaya masyarakat desa setempat. Peraturan Desa dilarang bertentangan dengan kepentingan umum dan/atau peraturan perundang-undangan yang lebih tinggi. Masyarakat berhak memberikan masukan secara lisan atau tertulis dalam rangka penyiapan atau pembahasan rancangan Peraturan Desa. untuk melaksanakan Peraturan Desa, Kepala Desa menetapkan Peraturan Kepala Desa dan Keputusan Kepala Desa. Nama istilah Peraturan Desa dapat bervariasi di indonesia.

Jenis peraturan di desa adalah Peraturan Desa, peraturan bersama Kepala Desa, Peraturan Kepala Desa. Peraturan Desa ditetapkan oleh Kepala Desa setelah dibahas dan disepakati bersama Badan Permusyawaratan Desa, rancangan Peraturan Desa tentang APBDesa, pungutan, tata ruang dan organisasi masyarakat desa harus mendapat evaluasi dari Bupati/Walikota. Peraturan Desa dan Peraturan Kepala Desa diundangkan dalam lembaran desa dan berita desa oleh sekretaris desa. Sedangkan peraturan bersama Kepala Desa ditetapkan oleh kepala desa dari 2 desa atau lebih yang melakukan kerjasama antar desa.

Menurut Undang-Undang No. 6 Tahun 2014 tentang Desa Pasal 1 angka 10 Keuangan desa adalah semua hak dan kewajiban Desa yang dapat dinilai dengan uang serta segala sesuatu berupa uang dan barang yang berhubungan dengan pelaksanaan hak dan kewajiban desa. Dimana dalam pengelolaan keuangan desa, salah satu perangkat desa yang dikenal dengan nama bendahara merupakan perangkat yang ditunjuk oleh kepala desa untuk menerima, menyimpan, menyetorkan, menatausahakan, membayarkan dan mempertanggungjawabkan keuangan desa dalam rangka pelaksanaan APBDes. APBDes adalah rencana keuangan tahunan Pemerintah Desa dan Badan Permusyawaratan Desa. Dana Desa (DD) adalah dana yang bersumber dari Anggaran Pendapatan dan Belanja Negara yang diperuntukkan bagi desa yang ditransfer melalui Anggaran Pendapatan dan Belanja Daerah kabupaten/kota dan digunakan untuk mendanai penyelenggaraan pemerintahan, pelaksanaan pembangunan, pembinaan kemasyarakatan, dan pemberdayaan masyarakat.

Dalam PP No8 Tahun 2016 Tentang dana desa yang ber sumber dari APBN dikemukakan bahwa dana desa setiap kabupaten/kota dihitung berdasarkan jumlah desa dan dialokasikan secara berkeadilan yaitu sebesar 90 persen dari dana desa dialokasikan secara merata ke setiap desa dan 10 persen dihitung dengan memperhatikan luas wilayah, jumlah penduduk, angka kemiskinan, dan tingkat kesulitan geografis desa. Dana desa adalah salah satu isu krusial dalam undang-undang desa, penghitungananggaranberdasarkanju mlahdesa dengan mempertimbangkan jumlah penduduk, angka kemiskinan, luas wilayah, dan tingkat kesulitan geografis, dalam rangka meningkatkan kesejahteraan dan pemerataan pembangunan desa. Karena isu yangbegitu krusial, parasenator menilai,penyelenggaraan pemerintahan desa membutuhkan pembinaan dan pengawasan, khususnya penyelenggaraan kegiatan desa.Pengalokasian Dana Desa setiap desa berdasarkan rincian dana desa setiap kabupaten/kota, bupati/walikota menghitung rincian dana desa setiap desa. Tata cara pembagian dan penetapan besaran Dana Desa ditetapkan dengan peraturan bupati/walikota. 


\section{METODE PENELITIAN}

Penelitian ini bertujuan untuk menggambarkan apakah Tata Cara Pengalokasian Dana Desa pada Peraturan Menteri Keuangan terhadap Pemerintah Kabupaten Lebong telah sesuai dengan peraturan yang berlaku sehingga dapat mengurangi kesenjangan pembangunan ekonomi antar wilayah di tingkat desa. Jenis data yang digunakan adalah data sekunder sedangkan sumber data dalam penelitian ini jumlah penduduk, luas wilayah, jumlah penduduk miskin dan indeks kesulitan geografis yang bersumber dari Badan Pusat Statistik Kabupaten Lebong dan data yang bersifat kuantitatif berupa rincian pagu dana desa setiap desa berdasarkan Peraturan Menteri Keuangan.

Setelah semua data dari hasil penelitian ini dikumpulkan dan dihitung maka data dikelompokkan menurut jenis dan sumbernya. Adapun metode analisis data yang digunakan adalah metode deskriptif kuantitaf, yakni data yang diperoleh dari Peraturan Menteri Keuangan dibandingkan dengan hasil yang dihitung dan di olah peneliti serta dianalisis.Apakah sudah terlaksana atau belum terlaksana sesuai dengan Peraturan Menteri Keuangan RI No.49 Tahun 2016 tentang Tata Cara Pengalokasian Dana Desa yang dijabarkan didalam Peraturan Bupati, kemudian diuraikan secara rinci untuk mencari penyelesaian.

\section{HASIL DAN PEMBAHASAN}

Pengalokasian dana desa yang dihitung telah dilakukan sesuai dengan rumus yang telah ditetapkan oleh PMK. Namun, terdapat selisih jumlah pagu dana desa setiap desa/kecamatan, antara jumlah pagu dana desa yang dihitung peneliti berdasarkan rumus yang ditetapkan oleh PMK dengan jumlah pagu yang ditetapkan menteri keuangan berdasarkan PMK, karena adanya perbedaan jumlah alokasi dana desa setiap desa/kecamatan maka pengalokasian dana desa secara proposional belum terlaksana dengan baik. Karena adanya perbedaan jumlah dana desa setiap desa/kecamatan, peneliti melakukan wawancara dengan pendamping desa dikecamatankecamatan yang terdapat selisih yaitu Kecamatan Bingin Kuning yang kurangnya jumlah dana desa paling besar yaitu sebesar Rp94.574.212,00, Kecamatan Lebong Selatan yang lebih jumlah dana nya paling banyak yaitu sebesar Rp167.720.749,00, dan Kecamatan Lebong Atas yang jumlah dana desa hampir sama hanya kurang Rp150.188,00 dengan mengemukakan selisih jumlah dana desa yang terjadi. Hasil wawancara tersebut ternyata Pemerintah Kabupaten Lebong tidak menggunakan data yang bersumber dari Badan Pusat Statistik, tetapi hanya berdasarkan laporan tahunan kepala desa pada tahun 2015, sedangkan tidak semua desa yang melakukan pendataan setiap tahunnya, ada desa yang melaporkan jumlah penduduk dan jumlah penduduk miskinnya menggunakan data tahun 2014. Menurut aturan yang ditetapkan oleh PMK yang mempengaruhi dalam Pengalokasian Dana Desa harus bersumber dari Badan Pusat Statistik.

Pagu Dana Desa yang dihitung dengan menggunakan data penentu yang bersumber dari lembaga yang berwenang maka akan tercapai asas yang adil dan merata. Hal ini harus menjadi pertimbangan bagi Pemerintah Daerah dalam melaksanakan serta mengeluarkan kebijakan yang berkaitan dengan Dana Desa. Agar Pagu Dana Desa yang diterima adil dan merata, dan penyelenggaraan pemerintahan didesa dapat berjalan sesuai tujuan yang dicita-citakan yakni meningkatkan dan memberdayakan pelayanan masyarakat.

Dilihat dari Peraturan Menteri Keuangan telah di tetapkan alokasi dasar memiliki nilai persentase yang besar yaitu $90 \%$ dibagi rata untuk semua desa tanpa mempertimbangkan kebutuhan dasar dari desa tersebut. Dimana desa yang lebih maju memperoleh jumlah dana yang sama dengan desa yang kurang maju. Sementara pengalokasian dana desa berdasarkan formula yang tersedia hanya $10 \%$ dari pagu anggaran dana desa dengan hanya 
mempertimbangkan 4 (empat) variabel yaitu jumlah penduduk, jumlah penduduk miskin, luas wilayah dan indeks kesulitan geografis tanpa memperhatikan kebutuhan dasar masyarakat desa. Jika dikaitkan dengan tujuan dari pengalokasian dana desa berdasarkan asas yang adil dan merata, hal ini belum mencapai sasaran yang adil dan merata.

Program Dana Desa dapat tercapai sesuai dengan tujuan yang diinginkan tidaklah mudah. Dalam pelaksanaan akan ditemukan kendala yang akan mempengaruhi terhambatnya proses pembangunan yang berorientasi pada perwujudan otonomi desa. Mencermati kondisi belum terlaksananya dengan baik pengalokasian dana desa di Kabupaten Lebong sebagai wujud otonomi desa tidak terlepas dari kesiapan dan komitmen dari Kabupaten dan Desa sebagai subjek dari program ini.

\section{PENUTUP}

\section{Simpulan}

Dari hasil analisa pengalokasian dana desa setiap desa/kecamatan ini, maka dapat ditarik kesimpulan sebagai berikut :

1. Pengalokasian dana desa sudah mengikuti petunjuk dari Peraturan Menteri Keuangan No 49 Tahun 2016 tentang Tata Cara Pengalokasian Dana Desa.

2. Hasil dari jumlah Pagu Dana Desa terdapat selisih di setiap desa/kecamatan hal ini disebabkan karena dalam pembobotan dana desa yang dikeluarkan berdasarkan PMK dengan menggunakan datayang di keluarkan oleh Pemerintah Kabupaten Lebong berdasarkan laporan tahunan kepala desa pada tahun 2015 ,sedangkan tidak semua desa yang melakukan pendataan setiap tahunnya, ada desa yang melaporkan jumlah penduduk dan jumlah penduduk miskinnya menggunakan data tahun 2014. Sedangkan menurut Peraturan Menteri Keuangan harus bersumber dari BPS.

\section{Implikasi Penelitian}

Berdasarkan kesimpulan penelitian diatas, maka implikasi dari penelitian ini adalah sebagai berikut :

1. Bagi Pemerintah Kabupaten Lebong, hasil penelitian ini dapat menjadi bukti empiris dan bahan evaluasi untuk pemerintahan dalam pengalokasian dana desa dan penyediaan sumber data di bidang statistik.

2. Bagi akademisi/mahasiswa, hasil penelitian ini diharapkan dapat mendorong dan memperkaya penelitian dalam bidang akuntansi sektor public sehingga dapat meningkatkan pengetahuan mengenai tata cara pengalokasian dana desa.

\section{Keterbatasan Penelitian}

Penelitian ini memiliki keterbatasan yang memerlukan perbaikan untuk penelitian selanjutnya. Sampel pada penelitian ini tidak semuanya ada di Badan Pusat Statustik Kabupaten Lebong dan data yang ada di BPS Kabupaten Lebong hanya jumlah penduduk dan luas wilayah. Sedangkan jumlah penduduk miskin diperoleh dari Dinas Pemberdayaan Masyarakat Desa dan Sosial, dan Indeks Kesulitan Georafis diperoleh di Badan Keuangan Daerah (BKD) Kabupaten Lebong. 


\section{Saran}

Berdasarkan kesimpulan dan keterbatasan diatas, peneliti menyarankan Badan Pusat Statistik Kabupaten Lebong dapat menyediakan data-data yang merupakan bobot dari pengalokasian dana desa. Dan Pemerintah Kabupaten Lebong dapat menggunakan data-data yang terdapat di Badan Pusat Statistik sesuai dengan peraturan yang berlaku.

\section{DAFTAR PUSTAKA}

Al-Fithrie, N. L. 2015. Pengaruh Moral Reasoning Dan Ethical Sensitivity Terhadap Persepsi Etis Mahasiswa Akuntansi Dengan Gender Sebagai Variabel Moderasi (Studi Kasus pada Mahasiswa Akuntansi UNY). Jurnal Universitas Negeri Yogyakarta. Vol. 3, No. 6 (2015).

Ajzen, I. 1991. The Theory of Planned Behavior. In: Organizational Behavior and Human Decision Process. Amherst, MA: Elsevier, 50: 179-211.

Dalimunthe, R. N. 2015. Pengaruh Penalaran Moral dan Kolektivisme Terhadap Niat Melakukan Whistleblowing (Studi Empiris Pada Mahasiswa Akuntansi S1 FEB UGM). Simposium Nasional Akuntansi 18.

Djumena, Erlangga. 2011. Inilah 9 Kasus Kejahatan Perbankan. Kompas, 3 Mei 2011 diakses dari http://bisniskeuangan.kompas.com/read/2011/05/03/09441743/Inilah.9.Kasus.Kejahatan.Per bankan pada tanggal 11 Desember 2016.

Elias, R. 2008. Auditing Students' Profession Their Relationship to Whistleblowing. Managerial Auditing Journal, 23, 283-294.

Faisal, 2007. Investigasi Tekanan Pengaruh Sosial dalam Menjelaskan Hubungan Komitmen dan Moral Reasoning Terhadap Keputusan Auditor. Simposium Nasional Akuntansi 10. 26-28 Juli 2007. Makasar.

Ghozali, Imam. 2009. Aplikasi Analisis Multivariate dengan Program SPSS, Edisi Keempat. Semarang: Penerbit Universitas Diponegoro.

Hofstede, G., and Hofstede, G. J. 2005. Cultures and organizations: Software of the mind. New York: McGraw Hill.

Keraf, A Sonny. 1998. Etika Bisnis Tuntutan dan Relevansinya. Yogyakarta: Kanisius.

Kohlberg, L. 2006. The Cognitive-Development Approach to Moral Education. Issues in adolescent psychology. New Jersey: Printice Hall, Inc.

Kreshastuti, D. K. 2014. Analisis Faktor-Faktor Yang Mempengaruhi Intensi Auditor Untuk Melakukan Tindakan Whistleblowing (Studi Pada Kantor Akuntan Publik Semarang). Jurnal Universitas Diponegoro Semarang, Vol 3, No.2, 1-15.

Liyanarachchi, G., and Newdick, C. 2009. The Impact of Moral Reasoning and Retaliation on Whistle-Blowing: New Zealand Evidence. Journal of Business Ethics, 89, 37-57.

Merdikawati, R., \& Prastiwi, A. 2012. Hubungan Komitmen Profesi dan Sosialisasi Antisipatif Mahasiswa Akuntansi dengan Niat Whistleblowing. Diponegoro Journal Of Accounting: Vol. I, No. 1.

Park, H., Rehg, M. T., and Lee, D. 2005. The Influence of Confucian Ethics and Collectivism on Whistleblowing Intentions: A Study of South Korean Public Employees. Journal of Business Ethics, 58, 387-403.

Setiawati, L.P dan Sari, M.R. 2016. Profesionalisme, Komitmen Organisasi, Intensitas Moral dan Tindakan Akuntan Melakukan Whistleblowing. Jurrnal Akuntansi Universitas Udayana. Vol. 17. 1, Oktober 2016: 257-282.

Singelis, T. M., Triandis, H. C., Bhawuk, D.P.S., Gelfand, M. J. 1995. Horizontal and Vertical Dimensions of Individualism and Collectivism: A Theoretical and Measurement Refinement. Cross-Cultural Research, 29, 240-275. 
Taylor, E.Z and Mary B. Curtis. 2010. An Examination Of The Layers Workplace Influence In Ethical Judgement: Whistleblowing Likelihood and Perseverance in Public Accounting. Journal of Business Ethics. 93, 21-37.

Triandis, H. C. 1995. Individualism and Collectivism. Boulder, CO: Westview.

Undang-undang Republik Indonesia, Nomor 10 Tahun 1998 tentang Perubahan Atas Undangundang Nomor 7 Tahun 1992 tentang Perbankan. 